\title{
Kinetic study of the degradation/mineralization of aqueous solutions contaminated with Rosuvastatin drug by Electro-Fenton: Influence of experimental parameters
}

\author{
N. Beqqal ${ }^{1}$, M. Sh. Yahya ${ }^{1}$, M. EL Karbane ${ }^{2}$, A. Guessous ${ }^{1}$, K. El Kacemi ${ }^{1}$ \\ 1. Laboratoire d'Électrochimie et Chimie Analytique (LECA), Faculté des Sciences, \\ Université Mohammed V Rabat, Morocco \\ 2. Service de Physico-chimie, Laboratoire de Contrôle Qualité des Médicaments, Division des Médicaments \\ et de Pharmacie, Ministère de la santé, Rabat, Maroc.
}

Received 12 Jan 2017,
Revised 22 Mar 2017,
Accepted 30 Mar 2017
Keywords
$\checkmark$ Statins;
$\checkmark$ Rosuvastatin;
$\checkmark$ Electro-Fenton;
$\checkmark$ Hydroxyl radicals;
$\checkmark$ Mineralization;
$\checkmark$ Chemical oxygen;
$\quad$ demand COD;
N.BEQQAL
$\quad$ bq.nesserine@gmail.com
$+\mathbf{+ 2 1 2 6 7 1 0 8 0 6 0 0}$

Received 12 Jan 2017 ,

Revised 22 Mar 2017,

Accepted 30 Mar 2017

Keywords

Statins;

Rosuvastatin

Electro-Fenton;

$\checkmark$ Hydroxyl radicals;

$\checkmark$ Mineralization;

Chemical oxygen

N.BEQQAL

$+212671080600$

\section{Introduction}

While, water is indispensable to the survival of all living beings, its pollution is a prevalent threat. In recent decades, a variety of synthetic organic compounds have been released into the environment as a result of human activities in urban, industrial and agricultural domains, ignoring the negative and harmful consequences of this irresponsible action. Their elimination remains incomplete during conventional wastewater treatment because of their persistence during biochemical degradation, their stability to radiation exposure in sunlight and their high resistance towards microbial attack and temperature [1-3].

Today, the detection of pharmaceutical residues (drugs) in environment is a major concern, since they increase the risk of toxicity to animals and humans [4-9].

Among these pharmaceutical residues detected, we find the statins which are inhibitors of HMG-CoA (3hydroxy-3-methylglutaryl coenzyme A) reductase, used in medicine to reduce cholesterol synthesis [10, 11]. Their consumption in Norway defined by daily doses per 1000 inhabitants reached 20 in 1996 and increased to 110 in 2004 [12]. The first statin named lovastatin was discovered in a terrus Aspergillus fermentation broth in 1978 by Merck Research Laboratory and was marketed in 1987, followed by simvastatin in 1988, pravastatin in 1991, fluvastatin in 1994, atorvastatin in 1997, cerivastatin in 1998 and rosuvastatin in 2003 [13]. Detailed research studies have demonstrated that statins also play an essential role in the prevention of cardiovascular disease [14], which explains remarkable increase in their demand in United Kingdom from 259000 prescriptions in 1981 to 52 millions in 2008 [15]. It was also shown that statins have pleiotropic effects that reduce inflammation and fight against sepsis [16-18]. 
In our study, we chose rosuvastatin (ROS) as a model of the new generation of statins because its high consumption in many countries, especially recently, it has been approved effective against Alzheimer's disease and promising in reducing cardiovascular risk factors [19-21]. According to World Health Organization (WHO), ROS is the third drug most sold in the US in 2012, which explains its detection in effluent (maximum concentration of $979 \mathrm{ng} \mathrm{L}^{-1}$ ) and its reaction as a contaminant in natural waters [22, 23]. Its metabolism is not enough, especially $77 \%$ of this substance is excreted unchanged $(90 \%$ unmetabolized is recovered in faeces and $10 \%$ in the urine) [24]. In addition, toxicity studies related to the high exposure of ROS on molds Lampsilis siliquoidea demonstrated the decrease in feed rate and the increase in time reserved for sub-adult mussels with their closed valves [25]. Another study noted that this drug is highly toxic and potentially carcinogenic due to the presence of pyrimidine derivatives [26]. In this regard, advanced treatment is required to remove organic materials in general and rosuvastatin in particular from contaminated waters by using effective and economical methods called advanced oxidation processes (AOPs) [27].

AOPs comprise an interesting and efficacious technique for the treatment of water polluted by organic pollutants [28], such as pharmaceuticals [29-33], pesticides [34], and dyes [35,36]. Their mechanism is based on the in situ generation of highly oxidizing and non-selective species such as hydroxyl radicals ${ }^{\bullet} \mathrm{OH}$, capable of handling all the different types of contaminated waters by different types of organic pollutants to obtain total mineralization into $\mathrm{CO}_{2}$, water and inorganic ions. Their oxidation potential is $\mathrm{E}^{\circ}\left(\cdot \mathrm{OH} / \mathrm{H}_{2} \mathrm{O}\right)=2.8 \mathrm{~V} /$ SHE [27, 37]. The production of these radicals can be achieved by chemical methods (ozonation $\mathrm{O}_{3}$, peroxonation $\mathrm{H}_{2} \mathrm{O}_{2} / \mathrm{O}_{3}$ ), photochemical processes (photodissociation direct $\mathrm{UV}$ photolysis of ozone $\mathrm{O}_{3} / \mathrm{UV}$, photoperoxonation $\mathrm{O}_{3} / \mathrm{H}_{2} \mathrm{O}_{2} / \mathrm{UV}$, photolysis of $\mathrm{H}_{2} \mathrm{O}_{2}$, photo-Fenton $\mathrm{H}_{2} \mathrm{O}_{2} / \mathrm{Fe}^{2^{+}} / \mathrm{UV}$, heterogeneous photocatalysis $\left(\mathrm{TiO}_{2}\right)$ and direct electrochemical processes ( anodic oxidation) or indirect (electro-Fenton process). These methods have significant remarkable benefits; they are versatile, environmentally friendly, provide better security with simple handling conditions and ensure a high yield [2].

Particular attention is given in recent years to electro-Fenton (EF) process as a technical high performance process based on continuous electrogeneration of $\mathrm{H}_{2} \mathrm{O}_{2}$ in acid solution by reduction to 2 electrons of oxygen (reaction 1) to the cathode as mercury pool [38, 39], carbon felt CF [40-42], activated carbon fiber [43], carbon nanotubes-polytetrafluoroethylene PTFE [44], carbon nanotubes immobilized onto graphite fiber [45], carbon PTFE gas diffusion electrodes GDE [46].

$\mathrm{O}_{2}+2 \mathrm{H}^{+}+2 \mathrm{e}^{-} \longrightarrow \mathrm{H}_{2} \mathrm{O}_{2}$

Note that $\mathrm{H}_{2} \mathrm{O}_{2}$ is a green chemical and environmentally friendly because it produces oxygen and water. It is very useful in cleaning electronic circuits and disinfection of medical materials [47]. However, it presents an inconvenience of limited oxidation capacity in the case of wastewater treatment since it attacks just cyanide, aldehydes, nitroorganic and sulfoorganic compounds, but its oxidizing power is significantly improved in the acidic medium by adding $\mathrm{Fe}^{2+}$ or $\mathrm{Fe}^{3+}$ as catalyst, giving the Fenton reagent which produces hydroxyl radicals $(\cdot \mathrm{OH})$ by the Fenton reaction $2[48,49]$.

$\mathrm{Fe}^{2+}+\mathrm{H}_{2} \mathrm{O}_{2} \longrightarrow \mathrm{Fe}^{3+}+\cdot \mathrm{OH}+\mathrm{OH}^{-}$

Interestingly, the propagation of the reaction (2) is provided by the continuous electrogeneration of $\mathrm{Fe}^{2+}$ from the reduction of $\mathrm{Fe}^{3+}$, formed during the reaction at the cathode with $\mathrm{E}_{0}=0.77 \mathrm{~V} / \mathrm{SHE}$ [48] according to the following reaction scheme (3) [50-52]:

$\mathrm{Fe}^{3+}+\mathrm{e}^{-} \longrightarrow \mathrm{Fe}^{2^{+}}$

Hydroxyl radicals $(\cdot \mathrm{OH})$ can be produced by the oxidation of water at the anode as the platinum $\mathrm{Pt}[53,55]$ or BDD electrode [56, 57].

There are a few studies concerning the degradation of rosuvastatin but none approached the EF process; we have found photocatalytic degradation of rosuvastatin using $\mathrm{ZnO}$ catalyst in suspension [58] and in demineralised water [20]. These studies demonstrated that ROS is classified as a moderately degradable compound and the effectiveness of this process can be influenced by the presence of dissolved Zno [20]. Another study of degradation of rosuvastatin by wastewater treatment plants (WWTP) showed that the degradation rate in sludge was higher than in water because of the presence of many bacteria with a variety of enzymes Capable of catalyzing the processes of degradation of ROS. In addition, this treatment can cause secondary pollution of the environment [59]. Therefore, the present study investigates the performance of the EF process for the efficient removal of ROS. 
This work aims at studying the oxidative destruction and mineralization of rosuvastatin's solutions by EF process using platinum (Pt) as anode and carbon felt as cathode. The effectiveness of this method in the degradation of ROS is assessed by the chemical oxygen demand (COD) by analyzing several parameters such as applied current, concentration and nature of catalyst, $\mathrm{pH}$, and supporting electrolyte.

\section{Materials and Methods}

\subsection{Chemical Reagents}

Rosuvastatin calcium (98\% purity) was purchased from Sigma Aldrich and used as received. Its chemical structure and physical properties are given in Table 1 . Anhydrous sodium sulfate $\mathrm{Na}_{2} \mathrm{SO}_{4}$ and Sodium chloride $\mathrm{NaCl}$ used as background electrolyte are also of analytical grade from Sigma Aldrich and Fluka, respectively. Heptahydrated ferrous sulfate and copper (II) sulfate pentahydrate used as catalyst are of analytical grade from Acros. Solutions were prepared with high-purity water obtained from a Millipore Milli-Q system with resistivity $>18 \mathrm{MG}$ at $25^{\circ} \mathrm{C}$. $\mathrm{pH}$ is adjusted with analytical grade sulfuric acid and sodium hydroxyd from Sigma Aldrich and Fluka, respectively, using HANNA pH-meter. Organic solvents and other chemicals such as Acetonitril (ACN), acetic acid and hydroxyamonium (HPLC grade, Carlo erpa) were used as received. Potassium chloride $(\mathrm{KCl})$, Mercuric sulfate $\mathrm{HgSO}_{4}$, silver sulfate $\mathrm{AgSO}_{4}$ and potassium dichromate $\mathrm{K}_{2} \mathrm{CrO}_{7}$ were purchased from Hach Lange Europe, Belgium.

Table 1: Rosuvastatin calcium properties

Compound
$\begin{aligned} & \text { calcium bis[(3R,5S,6E)- } \\ & \text { 7-\{4-(4-fluoro-phenyl)- } \\ & \text { 6-(1-methylethyl)-2- } \\ & \text { aming](my)thylsulfony) } \\ & \text { 3,5-dihydroxyhept-6- } \\ & \text { enoate] }\end{aligned}$

\subsection{Experimental setup}

To control the current intensity, a potentiostat/galvanostat model PGZ 301 associated to Voltalab was utilized during electrolysis. The experiments were performed using a cylindrical and open undivided cell of $6 \mathrm{~cm}$ diameter and $250 \mathrm{ml}$ capacity. The anode is a platinum electrode of $5 \mathrm{~cm}^{2}$, placed on the center of the cell and surrounded by a large surface area three-dimensional carbon-felt $(10 \mathrm{~cm} \times 7 \mathrm{~cm} \times 0,5 \mathrm{~cm}$ - carbone Lorraine $)$ used as cathode. The initial $\mathrm{pH}$ of solutions was adjusted to 3 by $0.1 \mathrm{M} \mathrm{H}_{2} \mathrm{SO}_{4}$. Moderate compressed air was bubbled during 10 minutes through the cell to saturate $200 \mathrm{ml}$ of aqueous solution, which was agitated continuously by a magnetic stirrer. Prior to the electrolysis, a catalytic amount $(0.1 \mathrm{mM})$ of Heptahydrated ferrous sulfate was added to the solution.

\subsection{Analytical methods}

\subsubsection{High Performance Liquid Chromatography (HPLC)}

The evolution of Rosuvastatin concentrations was detected using a Waters 2695, fitted with Zorbax eclipse XDB C18 column $(150 \mathrm{~mm} / 4,6 \mathrm{~mm} / 3,5 \mu \mathrm{m})$ at $25{ }^{\circ} \mathrm{C}$, equipped with an isocratic pump and photodiode array PDA 2260 detector selected at optimum wavelength of $248 \mathrm{~nm}$. The mobile phase was a mixture of ACN/acetic acid (30:70, v/v). It was eluted with a rate of $1 \mathrm{ml}^{\mathrm{min}}{ }^{-1}$. The injection volume was $130 \mu \mathrm{L}$.

\subsubsection{Chemical oxygen demand (COD)}

The mineralization of Rosuvastatin solution was followed by chemical oxygen demand (COD) using the Lovibond $^{\circledR}$ Vario-MD200 Photometer. The amount of oxygen required for the oxidation of the organic matter at $150{ }^{\circ} \mathrm{C}$ for $2 \mathrm{~h}$ was quantified after oxidation with $\mathrm{K}_{2} \mathrm{Cr}_{2} \mathrm{O}_{7}$ in acidic medium [61]. COD values were measured colorimetrically using DR/125 spectrophotometer (Hach company, USA). 


\section{Results and Discussion}

The Electro Fenton process, though simple in principle, involves a number of experimental parameters including optimization which governs the efficiency of the degradation of organic pollutants.

\subsection{Effect of applied current}

Given its role in regulating the amount of hydroxyl radicals generated in electrolysis, the applied current settings affect the oxidation capacity of Electro-Fenton process.

Degradation kinetics experiments were performed at room temperature in an acidic medium $(\mathrm{pH} 3)$ in the presence of $0.1 \mathrm{mM} \mathrm{Fe}^{3+}$ and $0.05 \mathrm{M} \mathrm{Na}_{2} \mathrm{SO}_{4}$ at a variable range of the applied current from $30 \mathrm{~mA}$ to 300 $\mathrm{mA}$. The decay of the initial concentration of rosuvastatin $\left(50 \mathrm{mg} \mathrm{L}^{-1}\right)$ was monitored by HPLC.

As shown in Figure 1, ROS is completely eliminated at 20, 12, 12, and $7 \mathrm{~min}$ for 30, 60, 100 and $300 \mathrm{~mA}$, respectively. This increase in degradation rate as the increase of the applied current may be related to the acceleration of the production of $\mathrm{H}_{2} \mathrm{O}_{2}$ and the catalytic cycle $\mathrm{Fe}^{3+} / \mathrm{Fe}^{2+}$, resulting in improving the generation of the hydroxyl radicals. The best degradation appears at $300 \mathrm{~mA}$ current.

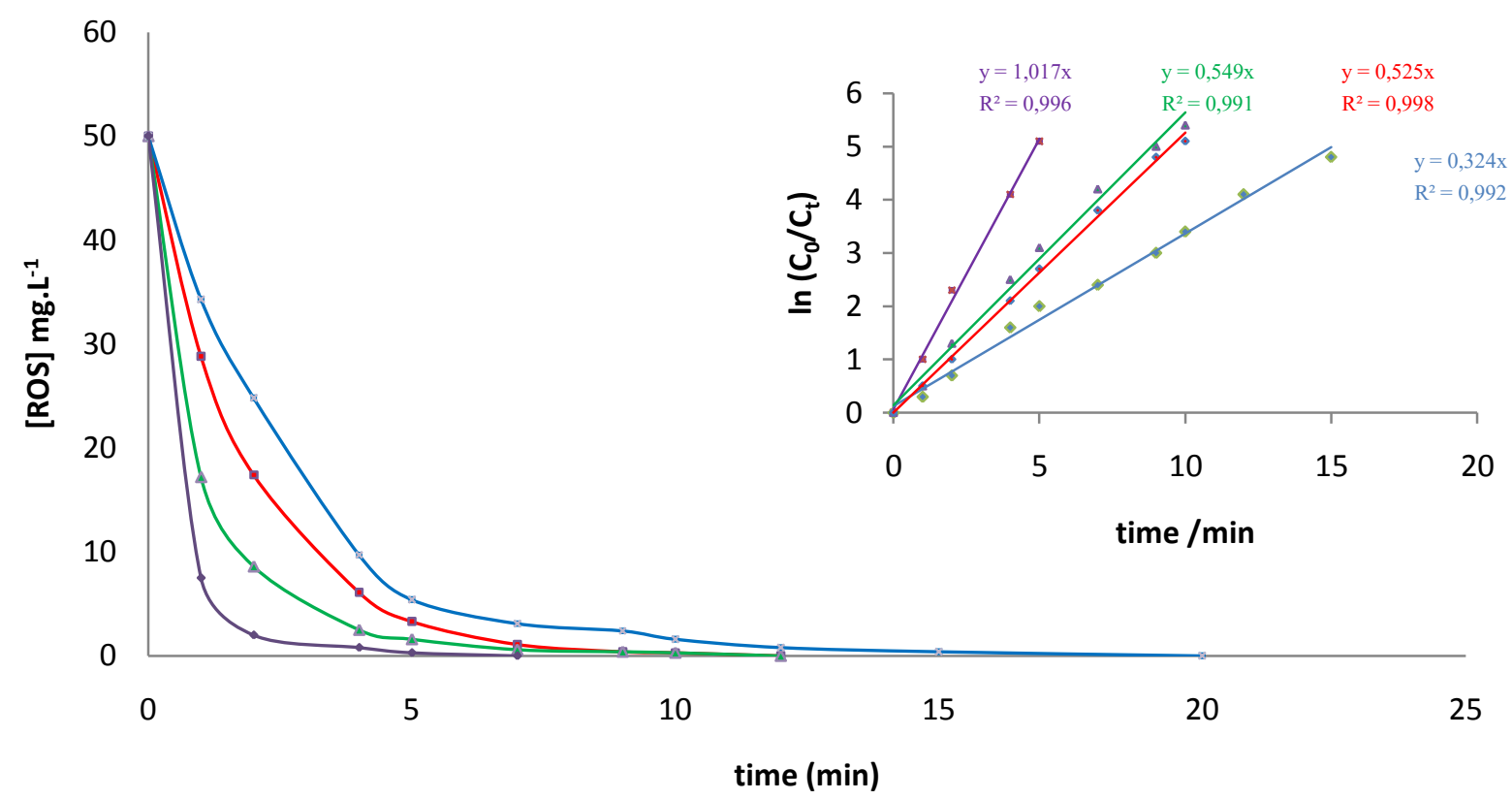

Figure 1: Effect of the applied current on the kinetic of the rosuvastatin degradation at $\mathrm{pH} 3.0$ at room temperature during the Electro-fenton process. Operating conditions: $[R O S]=0.05 \mathrm{mM},\left[\mathrm{Fe}^{3+}\right]=0.1 \mathrm{mM}$, $\left[\mathrm{Na}_{2} \mathrm{SO}_{4}\right]=0.05 \mathrm{M}, \mathrm{V}=200 \mathrm{ml}, \mathrm{I}(\mathrm{mA}): 30(->-), 60(--), 100(-\Delta-), 300(-x-)$. Inset panels show the kinetics analysis considering a pseudo-first order reaction between ROS and ${ }^{\circ} \mathrm{OH}$, this analysis allowed determining apparent rate constants.

The decrease in the concentration of ROS follows a pseudo-first order kinetic equation. This behavior is an accordance with a previous study concerning the degradation of ROS in aqueous solutions [20] [58,59]. The value of the apparent rate constant $K_{\text {app }}$ is found to be $0.32 \mathrm{~min}^{-1}\left(\mathrm{R}^{2}=0.992\right)$ at $30 \mathrm{~mA}, 0.53 \mathrm{~min}^{-1}\left(\mathrm{R}^{2}=\right.$ $0.998)$ at $60 \mathrm{~mA}, 0.55 \mathrm{~min}^{-1}\left(\mathrm{R}^{2}=0.991\right)$ at $100 \mathrm{~mA}$, and $1.02 \mathrm{~min}^{-1}\left(\mathrm{R}^{2}=0.996\right)$ at $300 \mathrm{~mA}$.

\subsection{Effect of $\mathrm{Fe}^{3+}$ catalyst}

The concentration of $\mathrm{Fe}^{3+}$ ions is considered another important parameter in EF process. In order to optimize the conditions of this parameter the degradation of ROS was analyzed in the presence of different concentrations of $\mathrm{Fe}^{3+}$ ions in an acid medium (pH 3) while applying a constant current of $300 \mathrm{~mA}$.

As shown in Figure 2, the better degradation of ROS was obtained for $0.2 \mathrm{mM}$ concentration (7 minutes), which explains that the amount of iron is ideal for improving the production of strong oxidants.

For $0.5 \mathrm{mM}$ concentration, degradation requires more time $(9 \mathrm{~min})$ for the complete elimination. This is probably associated with a progressive decrease in production of hydroxyl radical ${ }^{\circ} \mathrm{OH}$ because of the large amounts of $\mathrm{Fe}^{2+}$ formed due to added $\mathrm{Fe}^{3+}$, accelerating the participation of non-oxidative reactions 4 .

$\mathrm{Fe}^{2+}+\cdot \mathrm{OH} \longrightarrow \mathrm{Fe}^{3+}+\mathrm{OH}^{-}$ 
To $0.1 \mathrm{mM}$ concentration, the time for degradation is the same as that of $0.2 \mathrm{mM}$ concentration, except that the yield is low. This negative effect can be associated with the insufficient amount of iron added to the top of the reaction, which gives an insufficient production of hydroxyl radicals. Degradation of ROS follows a pseudofirst order reaction kinetics, the values of the apparent rate constants are $1.06 \mathrm{~min}^{-1}\left(\mathrm{R}^{2}=0.970\right), 1.02 \mathrm{~min}^{-1}$ $\left(\mathrm{R}^{2}=0.996\right)$ and $0.87 \mathrm{~min}^{-1}\left(\mathrm{R}^{2}=0.960\right)$ for $0.2,0.1$ and $0.5 \mathrm{mM}$ respectively.

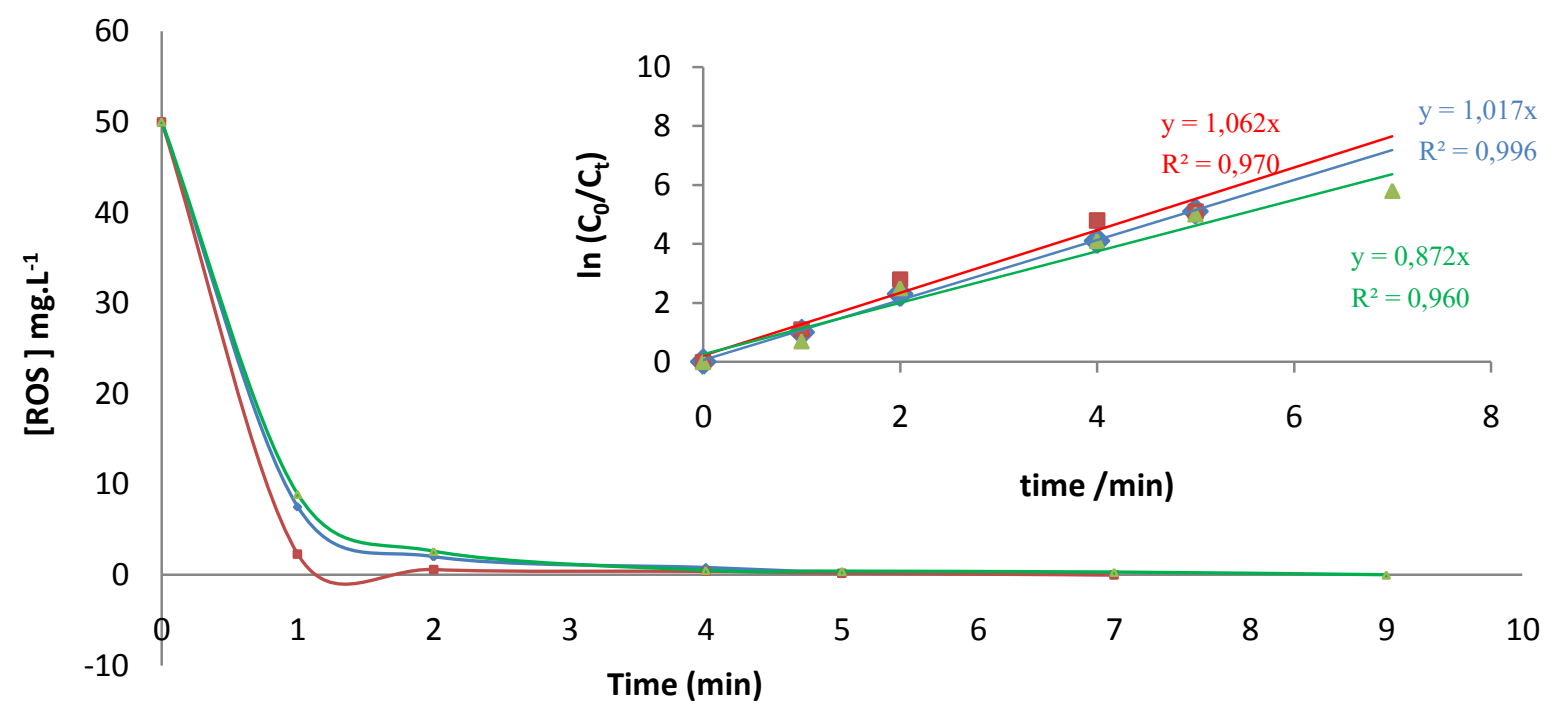

Figure 2: Influence of the $\mathrm{Fe}^{3+}$ (Catalyst) concentration on the decay kinetics of rosuvastatin. Operating conditions : $[\mathrm{ROS}]=0.05 \mathrm{mM},\left[\mathrm{Na}_{2} \mathrm{SO}_{4}\right]=0.05 \mathrm{M}, \mathrm{V}=200 \mathrm{ml}, \mathrm{I}=300 \mathrm{~mA}$. $\left[\mathrm{Fe}^{3+}\right](\mathrm{mM}): 0.1(-\downarrow), 0.2(--)$, $0.5\left(-\Delta_{-}\right)$. Inset panels show the kinetics analysis considering a pseudo-first order reaction between ROS and $\bullet \mathrm{OH}$, this analysis allowed determining apparent rate constants.

\section{Study of the mineralization process}

\subsection{Effect of applied current on Rosuvastatin mineralization by EF}

The generation of $\bullet \mathrm{OH}$ is controlled by a very important parameter: applied current I. Its influence has been clarified by the electrolysis of $0.05 \mathrm{mM}$ of ROS in the presence of $0.05 \mathrm{M} \mathrm{Na}_{2} \mathrm{SO}_{4}$ and $0.1 \mathrm{mM} \mathrm{Fe}^{3+}$ between 30 and $300 \mathrm{~mA}$ at $\mathrm{pH} 3$ for 6 hours of treatment. It has been observed in Figure 3 that an increase in the applied current clearly improves the mineralization rates. COD was reduced by $40 \%, 73 \%, 76 \%$ and $83 \%$ at 30, 60, 100 and $300 \mathrm{~mA}$, respectively. From these results, the current $300 \mathrm{~mA}$ appears to be the best current for mineralization with optimized rate.

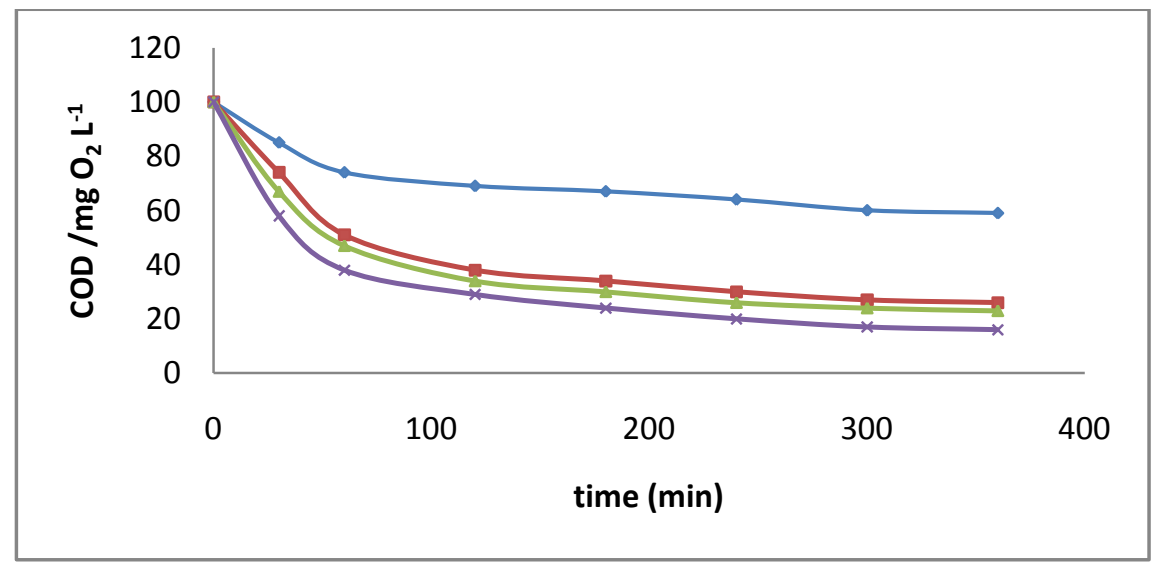

Figure 3 : Influence of current applied on the mineralization solutions of rosuvastatin by the Electro-Fenton. Operating conditions: $[\mathrm{ROS}]=0.05 \mathrm{mM} .\left[\mathrm{Fe}^{3+}\right]=0.1 \mathrm{mM},\left[\mathrm{Na}_{2} \mathrm{SO}_{4}\right]=0.05 \mathrm{M}, \mathrm{V}=200 \mathrm{ml}, \mathrm{I}(\mathrm{mA}): 30(-\downarrow-)$,

\subsection{Effect of $\mathrm{Fe}^{3+}$ concentration}

In this part, we study the influence of the concentration of $\mathrm{Fe}^{3+}$ catalyst for the mineralization of ROS. That was achieved by the treatment of aqueous solutions containing ROS $(0.05 \mathrm{mM})$ under the following operating conditions: Ambient temperature, $\mathrm{pH} 3$, current applied $300 \mathrm{~mA}$, nature and concentration of supporting 
electrolyte $0.05 \mathrm{M} \mathrm{Na}_{2} \mathrm{SO}_{4}$ and concentration of $\mathrm{Fe}^{3+}$ catalyst varying from 0.1 to $0.5 \mathrm{mM}$. After treatment for 6 hours, the obtained results in Figure 4 show that the mineralization rate was $82 \%, 94 \%, 70 \%$ for concentrations of iron $0.1,0.2$ and $0.5 \mathrm{mM}$, respectively. Mineralization rate is optimum for $0.2 \mathrm{mM}$ concentration. Similar observations have been reported in the previous studies [62, 63].

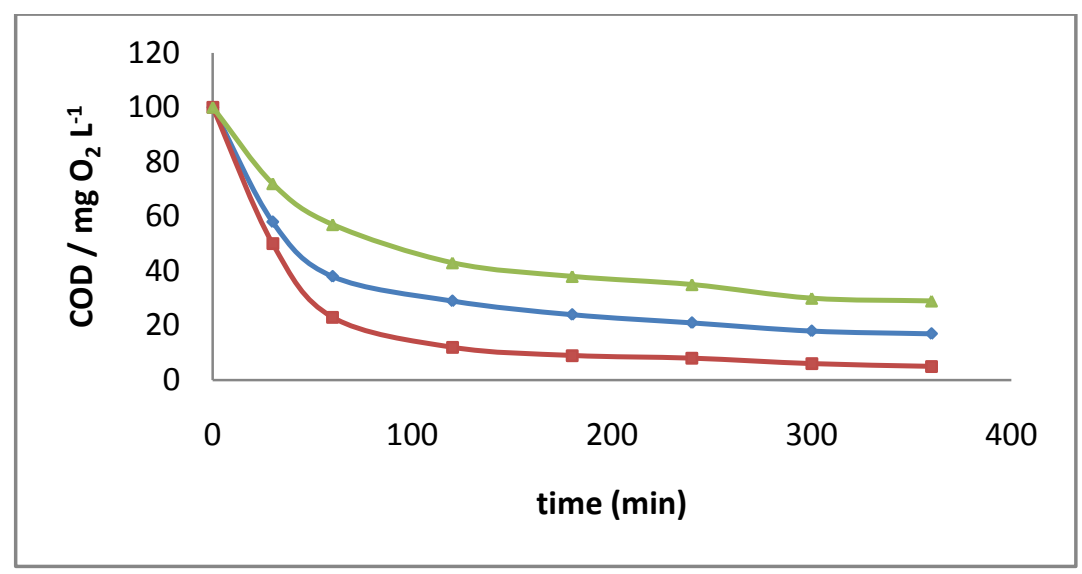

Figure 4: Influence of iron concentration for mineralization during Electro-fenton. Operating conditions: $[\mathrm{ROS}]=0.05 \mathrm{mM},\left[\mathrm{Na}_{2} \mathrm{SO}_{4}\right]=0.05 \mathrm{M}, \mathrm{V}=200 \mathrm{ml}, \mathrm{I}=300 \mathrm{~mA} .\left[\mathrm{Fe}^{3+}\right](\mathrm{mM}): 0.1(-\downarrow-), 0.2(--), 0.5(-\Delta-)$.

\subsection{Effect of the nature of catalyst}

It is well known that iron (Ferrous $\mathrm{Fe}^{2+}$ or Ferric $\mathrm{Fe}^{3+}$ ) is the most commonly used for environmental and economic criteria catalyst, but that does not prevent other transition metal ions serving as a catalyst, alone or combined. For this reason, the study of mineralization aqueous solutions of ROS was carried out in the presence of $\mathrm{Cu}^{2+}$ ions alone whose concentration was set to $0.2 \mathrm{mM}$ [51] , in order to compare the performance of various catalysts. The results according to Figure 5 evidence that Ferric ions lead to the best mineralization relative to cuprous ions in the same concentration. This can be caused because of the greater oxidizing power of the couple $\mathrm{Fe}^{3+} / \mathrm{Fe}^{2+}\left(\mathrm{E}_{0}=0.77 \mathrm{~V} / \mathrm{SHE}\right)$ compared to that of the couple $\mathrm{Cu}^{2+} / \mathrm{Cu}^{+}\left(\mathrm{E}_{0}=0.16 \mathrm{~V} / \mathrm{SHE}\right)$, thus explaining the low production of $\cdot \mathrm{OH}$ by the Fenton-Like resulting from the reaction between $\mathrm{Cu}^{+}$and $\mathrm{H}_{2} \mathrm{O}_{2}$ (reaction 5) [64]:

$\mathrm{H}_{2} \mathrm{O}_{2}+\mathrm{Cu}^{+} \longrightarrow \mathrm{Cu}^{2+}+\mathrm{OH}^{-}+\cdot \mathrm{OH}$

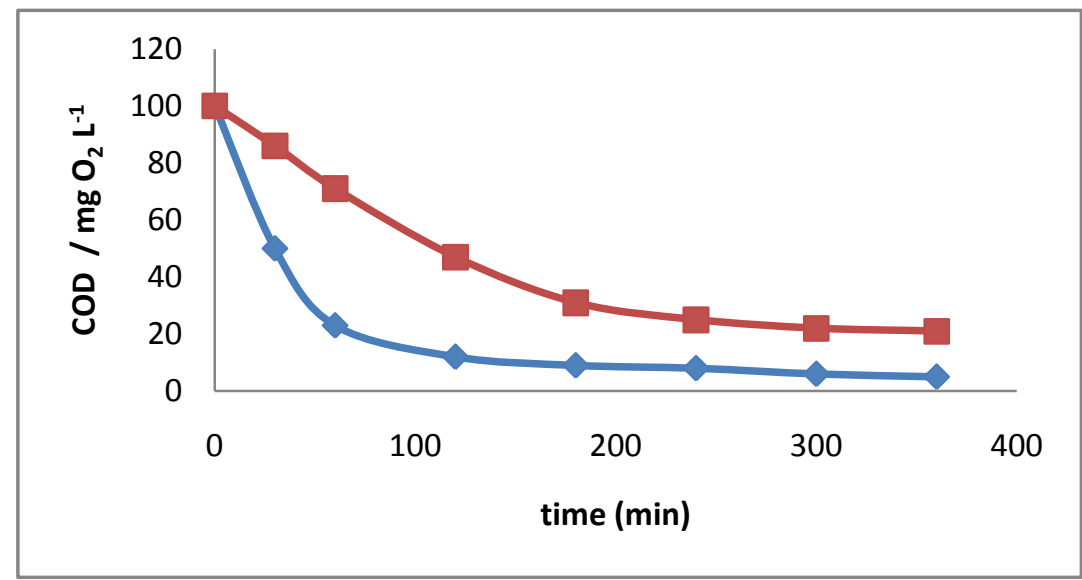

Figure 5: Influence of the nature of the catalyst on the mineralization of aqueous solutions of rosuvastatin. Operating conditions: $[\mathrm{ROS}]=0.05 \mathrm{mM}$. I $=300 \mathrm{~mA},\left[\mathrm{Na}_{2} \mathrm{SO}_{4}\right]=0.05 \mathrm{M}, \mathrm{V}=200 \mathrm{ml},\left[\mathrm{Fe}^{3+}\right]=0.2 \mathrm{mM}(-\downarrow-)$, $\left[\mathrm{Cu}^{2+}\right]=0.2 \mathrm{mM}(--)$.

\subsection{Effect of $p H$ solution}

Several experiments were conducted to demonstrate the influence of $\mathrm{pH}$ in EF process. The selected $\mathrm{pH}$ values are 2, 3, 4 and 5. This was adjusted by either $\mathrm{NaOH}$ or $\mathrm{H}_{2} \mathrm{SO}_{4}$ while maintaining the other parameters constant $\left([R O S]=0.05 \mathrm{mM}, \mathrm{I}=300 \mathrm{~mA},\left[\mathrm{Fe}^{3+}\right]=0.2 \mathrm{mM},\left[\mathrm{Na}_{2} \mathrm{SO}_{4}\right]=0.05 \mathrm{M}\right)$. Figure 6 shows that after 6 hours of 
treatment, the rate of reduction was $91 \%, 94 \%, 59 \%$ and $10 \%$ for the values of $\mathrm{pH} \mathrm{2,3,4}$ and 5, respectively. Therefore, the best production of hydroxyl radicals was observed for $\mathrm{pH} 3$ and hence better mineralization. Several studies have confirmed this result and that the optimum $\mathrm{pH}$ value during the EF process is $2.8-3.0$ [49] [65, 66]. The low reduction rate observed at higher $\mathrm{pH}$ value of 5 can be explained on the basis of the instability of ferric ions which can form precipitates $\mathrm{Fe}(\mathrm{OH})_{3}$ and therefore a decline in the generation of hydroxyl radicals. To $\mathrm{pH} 4$, the result obtained is due to the disappearance of ferric ions because of the hydroxyl processing as $[\mathrm{Fe}(\mathrm{OH})]^{2+},\left[\mathrm{Fe}(\mathrm{OH})_{2}\right]^{+}$and $\left[\mathrm{Fe}\left(\mathrm{OH}_{2}\right)_{2}\right]^{+}$or complex hydroperoxy as $\left[\mathrm{Fe}(\mathrm{OH})\left(\mathrm{H}_{2} \mathrm{O}_{2}\right)\right]^{+}$ [49] [67-69]. Around $\mathrm{pH} 2$, the transformation of $\mathrm{H}_{2} \mathrm{O}_{2}$ to $\mathrm{H}_{3} \mathrm{O}_{2}{ }^{+}$and oxonium by capturing one proton $\mathrm{H}^{+}$ explains clearly the slower reaction between $\mathrm{H}_{2} \mathrm{O}_{2}$ and iron $[70,71]$

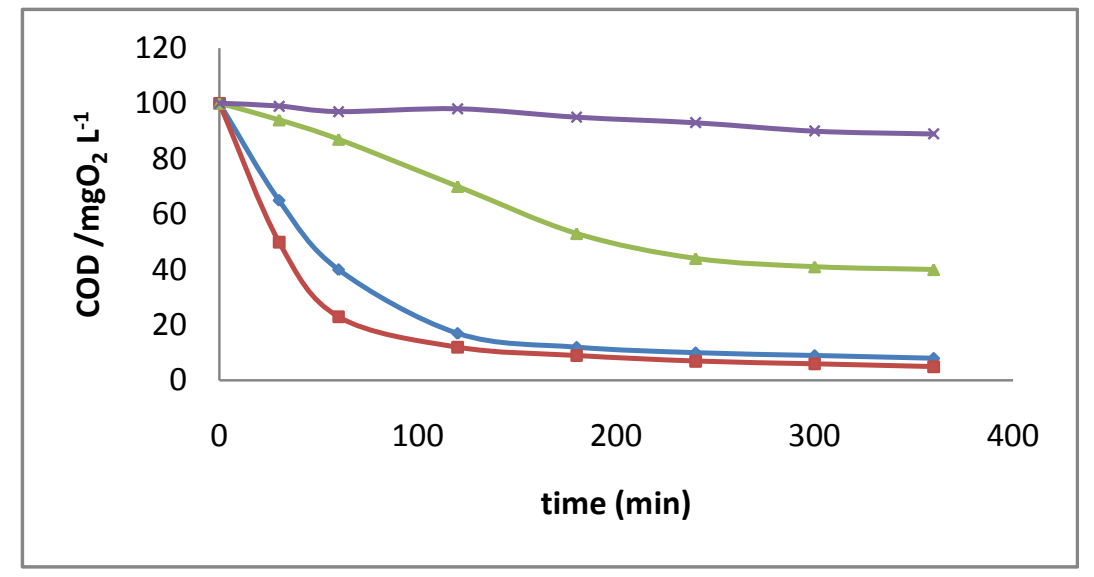

Figure 6: Influence of $\mathrm{pH}$ on the mineralization of aqueous solutions of ROS in the Electro-Fenton. Operating conditions: $[\mathrm{ROS}]=0.05 \mathrm{mM} .\left[\mathrm{Fe}^{3+}\right]=0,2 \mathrm{mM},\left[\mathrm{Na}_{2} \mathrm{SO}_{4}\right]=0.05 \mathrm{M}, \mathrm{V}=200 \mathrm{ml}, \mathrm{I}=300 \mathrm{~mA}, \mathrm{pH}: 2\left(--_{-}\right), 3(--)$, $4(-\Delta-), 5(-x-)$.

\subsection{Effect of supporting electrolyte}

To study the effect of the supporting electrolyte, two reagents were selected $\mathrm{Na}_{2} \mathrm{SO}_{4}$ and $\mathrm{NaCl}$. The comparison between the reduction of ROS in the presence of these two reactants is clearly shown in Figure 7.

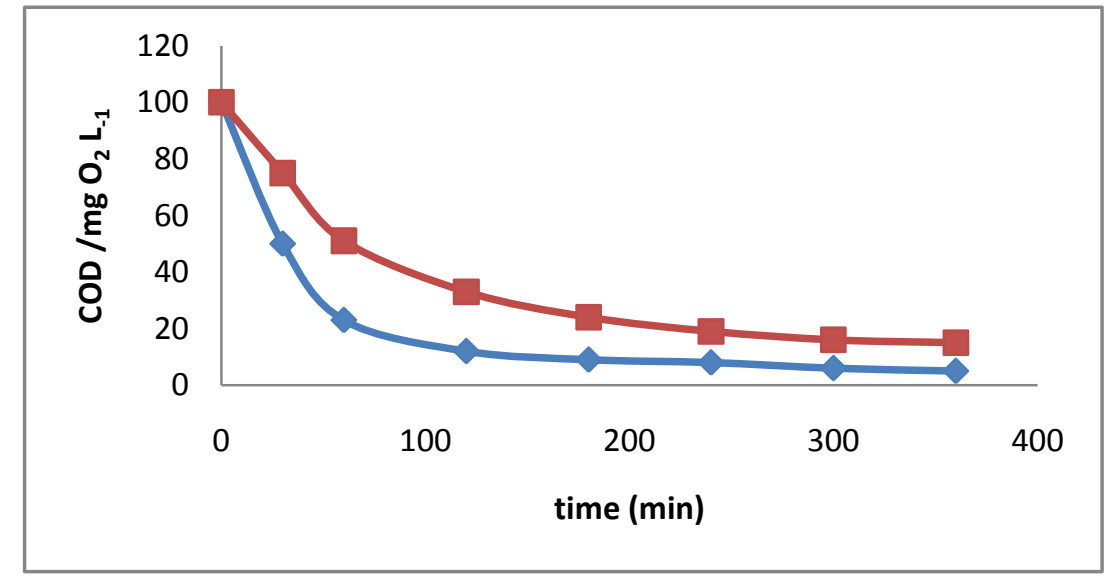

Figure 7: Influence of electrolyte support on the mineralization of aqueous solutions of ROS. Operating conditions: $[\mathrm{ROS}]=0.05 \mathrm{mM} .\left[\mathrm{Fe}^{3+}\right]=0,2 \mathrm{mM}, \mathrm{V}=200 \mathrm{ml}, \mathrm{I}=300 \mathrm{~mA}, \mathrm{pH} 3,\left[\mathrm{Na}_{2} \mathrm{SO}_{4}\right]=0.05 \mathrm{M}(-\downarrow)$, $[\mathrm{NaCl}]=0.1 \mathrm{M}(--)$.

The presence of $\mathrm{NaCl}$ does not accelerate the mineralization. This is due to oxidation of the chlorides ions which gives chlorines at anode pursuing the following equation 6 , and which also oxidizes iron ions according to reaction scheme 7, or decomposes $\mathrm{H}_{2} \mathrm{O}_{2}$ thus influencing the production of hydroxyl radicals [72] according to reaction scheme $8 . \mathrm{Na}_{2} \mathrm{SO}_{4}$ therefore seems the best supporting electrolyte.

$2 \mathrm{Cl}^{-} \longrightarrow \mathrm{Cl}_{2}+2 \mathrm{e}^{-}$ 


$$
\begin{aligned}
& 2 \mathrm{Fe}^{2+}+\mathrm{Cl}_{2} \longrightarrow 2 \mathrm{Fe}^{3+}+2 \mathrm{Cl}^{-} \\
& 3 \mathrm{H}_{2} \mathrm{O}_{2}+\mathrm{Cl}_{2} \longrightarrow 2 \mathrm{HCl}+2 \mathrm{H}_{2} \mathrm{O}+2 \mathrm{O}_{2}
\end{aligned}
$$

\section{Conclusions}

This study demonstrated the effectiveness of the of EF process for the improvement of the degradation of ROS. Changes in the parameters used, including the current applied, nature and concentration of catalyst, $\mathrm{pH}$, support electrolyte resulted in significant differences in the efficiency of this process.

By applying a current of $300 \mathrm{~mA}$ and a catalyst $\left(\mathrm{Fe}^{3+}\right)$ with concentration of $0.2 \mathrm{mM}$ in acidic medium (pH 3), a remarkable increase in the oxidation rate was observed.

The elimination of ROS reduced when $\mathrm{NaCl}$ was used as supporting electrolyte instead $\mathrm{Na}_{2} \mathrm{SO}_{4}$, because the electrogeneration of active chlorine species from chloride ions decreased the production of $\cdot \mathrm{OH}$. Similar results were shown when $\mathrm{Cu}^{2+}$ was used as catalyst instead $\mathrm{Fe}^{3+}$, which agrees with the lower production of $\cdot \mathrm{OH}$ from Fenton like reaction between $\mathrm{Cu}^{+}$and $\mathrm{H}_{2} \mathrm{O}_{2}$.

\section{References}

1. Doble M., Kumar A., Elsevier, Butterworth-Heinemann. (2005).

2. Martínez-Huitle C.A., Brillas E., Appl. Catal. B: Environ. 87 (2009) 105.

3. Heberer T., Journal of Hydrology. 266(3-4) (2002) 175-189.

4. Halling-Sørensen B., Nielsen S.N., Lanzky P.F., Ingerslev F., Lützhøft H.C.H., Jørgensen S.E., Chemosphere. 36 (1998) 357-393.

5. Heberer T., Toxicol. Lett. 131 (2002) 5-17.

6. Kümmerer K., J. Environ. Manage. 90 (2009) 2354-2366.

7. Khetan S.K., Collins T.J., Chem. Rev. 107 (2007) 2319.

8. Kümmerer K., Chemosphere. 75 (2009) 417.

9. Luo Y., Xu L., Rysz M., Wang Y., Zhang H., Alvarez P.J.J., Environ. Sci. Technol. 45 (2011) 1827.

10. Stancu C., Sima A., J. Cell Mol. Med. 4 (2001) 378-387.

11. Singh Grover H., Luthra S., Maroo S., Journal of the formation medical association 113 (2014) 892-898

12. Hartz I., Sakshaug S., Furu K., Engeland A., Eggen A.E., Njølstad I., Skurtveit S., BMC Pharmacol. Toxicol. 14 (2007) 7.

13. Schachter M., Fundam Clin Pharmacol. 19 (2005) 17-25.

14. Abbas A., Milles J., Ramachandran S., Clinical Medicine Insights: Endocrinology and Diabetes.5 (2012) $13-30$.

15. Trusler D., BMJ. 343 (2011) d 4350.

16. Hackam D.G., Mamdani M., Li P., Redelmeier D.A., Lancet. 8 (2006) 367- 413.

17. Koh K.K., Cardiovasc Res. 648 (2000) 47-57.

18. Kwak B.R., Mulhaupt F., Mach F., Autoimmun Rev. 2332 (2003) 2-8.

19. Goodman-Hilman A., Rall T., Nier A., Taylor P., The Pharmacological Basis of Therapeutics. (1996).

20. Segalin J., Sirtori C., Jank L., Lima M.F.S., Livotto R.P., Machado T.C., Lansarin M.A., Pizzolato T.M., Journal of Hazardous Materials.299 (2015) 78-85.

21. Mahalwar R., Khanna D., J. Pharmacol. 711 (2013) 57-62.

22. Loos R., Carvalho R., António D.C., Comero S., Locoro G., Tavazzi S., Paracchini B., Ghiani M., Lettieri T., Blaha L., Jarosova B., Voorspoels S., Servaes K., Haglund P., Fick J., Lindberg R.H., Schwesig D., Gawlik B.M., Water Res. 47 (2013) 6475-6487.

23. Lee H.B., Peart T.E., Svoboda M.L., Backus S., Chemosphere. 77 (2009) 1285-1291.

24. Hoffmann R., Langenberg R., Radke P., Franke A., Blindt R., Ortlepp J., Popma J.J., Weber C., Hanrath P., American Journal of Cardiology. 94 (2004) 193-195.

25. Gilroy E.A.M., Klinck J.S., Campbell S.D., McInnis R., Gillis P.L., Solla S.R., Sci. Total Environ. 487 (2014) 537-544.

26. Shah R.P., Sahu A., Singh S., Anal. Bioanal. Chem. 405 (2013) 3215-3231.

27. Brillas E., J. Mex. Chem. Soc. 58(3) (2014) 239-255.

28. Andreozzi R., Caprio V., Insola A., Marotta R., Catalysis Today. 53 (1999) 51-59.

29. Esplugas S., Bila D.M., Krause L.G.T., Dezotti M., J. Hazard. Mater. 149 (2007) 631.

30. Klavarioti M., Mantzavinos D., Kassinos D., Environ. Int. 35 (2009) 402.

31. Panizza M., Cerisola G., Chem. Rev. 109 (2009) 6541.

32. De Witte B., Dewulf Jo., Demeestere K., Van Langenhove H., J. Hazard. Mater. 161 (2009) 701- 708. 
33. Sirés I., Brillas E., Environ. Int. 40 (2012) 212.

34. Bobu M., Wilson S., Greibrokk T., Lundanes E., Siminiceanu I., Chemosphere .63 (2006) 1718-1727.

35. Karci A., Chemosphere 99 (2014) 1-18.

36. Zhou M., He J., Electrochim Acta. 53 (2007) 1902- 1910.

37. Malato S., Fernández-Ibánez P., Maldonado M.I., Blanco J., Gernjak W., Catalysis today 147 (2009) 1-59

38. Oturan M.A., Pinson J., Bizot J., Deprez D., Terlain B., J. Electroanal. Chem. 334 (1992b) 103-109.

39. Oturan M.A., Pinson J., Deprez D., Terlain B., New J. Chem. 16 (1992a) 705-710.

40. Aaron J.J., Oturan M.A., Turk. J. Chem., 25 (2001) 509-520.

41. Sires I., Garrido J.A., Rodrı'guez R.M., Brillas E., Oturan N., Oturan M.A., Appl. Catal. B-Environ., 72 (2007a) 382-394.

42. Kaplan ., Hesenov A., Gözmen B., Erbatur O., Environmental Technology. 32, 7 (2011) 685-692.

43. Wang A., Qu J., Liu, H., J. Appl. Catal. B: Environ. 84 (2008) 393.

44. Khataee A.R., Vahid B., Behjati B., Safarpour M., Environ. Progr. Sust. Energy. 32 (2013) 557.

45. Khataee A.R., Safarpour M., Naseri A., Zarei M., AR Journal of Electroanalytical Chemistry. 672 (2012) 53-62.

46. Isarain-Chávez E., Garrido J.A., Rodríguez R.M., Centellas F., Arias C., Cabot P. L., Brillas E., J. Phys. Chem. A. 115 (2011) 1234.

47. Pletcher D., Acta Chem. Scand. 53 (1999) 745.

48. Brillas E., Sirés I., Oturan M. A., Chem. Rev. 109 (2009) 6570.

49. Yunfu S., Pignatello J.J., Environ. Sci. Technol. 27 (2) (1993) 304-310.

50. Kaichouh G., Oturan N., Oturan M.A., El Kacemi K., El Hourch A., Environ. Chem. Lett. 2 (2004) 31-33.

51. Oturan N., Oturan M.A., Agron. Sustain. Dev. 25 (2005) 267-270.

52. Diagne M., Oturan N., Oturan M.A., Chemosphere 66 (2007) 841-848.

53. Yahya M.Sh., Oturan N., El Kacemi K., EL Karbane M., Aravindakumar C.T., Chemosphere .117 (2014) 447-454.

54. Yahya M.Sh., El Karbane M., Oturan N., El Kacemi K., Oturan M.A., Environmental Technology. 37:10 (2016) 1276-1287.

55. Yahya M.Sh., Beqqal N., Guessous A., Arhoutane M.R., El Kacemi K., Cogent Chemistry.3:1290021 (2017), https://doi.org/10.1080/23312009.2017.1290021

56. Panizza M., Michaud P.A., Cerisola G., Comninellis Ch., J. Electroanal. Chem. 507(1-2) (2001) 206-214.

57. Flox C., Cabot P.L., Centellas F., Garrido J.A., Rodríguez R.M, Arias C., Brillas E., Chemosphere. 64(6) (2006) 892-902.

58. Machado T.C., Pizzolato T.M., Arenzon A., Segalin J., Lansarin M.A., Science of the Total Environment .502 (2015) 571-577.

59. Sulaiman S., Khamis M., Nir S., Lelario F., Scrano L., Bufo S., Karaman R., Case Studies Journal ISSN (2305-509X) - Volume 4, Issue 6 - June 2015.

60. Kamble P.R., Shaikh K.S., Chaudhari P.D., Advanced Pharmaceutical Bulletin. 4(2) (2014) 197- 204.

61. Fourcade F., Yahiat S., Elandaloussi K., Brosillon S., Amrane A., Chem.Eng.Technol.35 (2012) 238.

62. Oturan M.A., Oturan N., Lahitte C., Trévin S., Journal of Electroanalytical Chemistry. 507 (2001) 96-102

63. Pérez M., Torrades F., Domènech X., Peral J., Water Research. 36 (2002) 2703-2710.

64. Pimentel M., Oturan N., Dezotti M., Oturan M.A., Applied Catalysis B: Environmental. 83 (2008) 140-9.

65. Masomboon N., Ratanatamskul C., Lu M.C., Appl. Catal. A: Gen. 384 (2010) 128-135.

66. Pignatello J., Oliveros E., MacKay A., Crit. Rev. Environ. Sci. Technol. 37 (3) (2006) 273-275.

67. Masomboon N., Ratanatamskul C., Lu M.C., J. Hazard.Mater. 176 (2010) 92-98.

68. Rosales E., Pazos M., Longo M.A., Sanroman M.A., Chem. Eng. J. 155 (2009) 62-67.

69. Estrada A.L., Li Y.Y., Wang A., Journal of Hazardous Materials. 227- 228 (2012) 41- 48

70. Jiang C.C., Zhang J.F., J. Zhejiang., Univ. Sci. A. 8 (2007) 1118-1125.

71. Panizza M., Barbucci A., Delucchi M., Carpanese M.P., Giuliano A., Cataldo-Hernandez M., Cerisola G., Journal of Electroanalytical Chemistry. 118 (2013) 394-398.

72. Loaiza-Ambuludi S., Panizza M., Oturan N., Özcan A., Oturan M.A., Journal of Electroanalytical Chemistry. 702 (2013) 31-36.

(2017) ; http://www.jmaterenvironsci.com 